\title{
Experiences from the implementation of sustainable development in higher education institutions: Environmental Management for Sustainable Universities
}

\author{
Tomás B. Ramos ${ }^{\mathrm{a}, *}$, Sandra Caeiro ${ }^{\mathrm{a}, \mathrm{b}}$, Bart van Hoof ${ }^{\mathrm{c}}$, Rodrigo Lozano ${ }^{\mathrm{d}}$, \\ Donald Huisingh ${ }^{e}$, Kim Ceulemans ${ }^{f}$ \\ ${ }^{a}$ Universidade Nova de Lisboa, CENSE - Center for Environmental and Sustainability Research, Department of Environmental Sciences and Engineering, \\ School of Science and Technology, Campus da Caparica, 2829-516 Caparica, Portugal \\ ${ }^{\mathrm{b}}$ Universidade Aberta, Department of Science and Technology, Rua Escola Politecnica, $n^{\circ}$ 141, 1269-001 Lisbon, Portugal \\ ${ }^{\mathrm{c}}$ Los Andes University, School of Management, Bogotá, Colombia \\ d Utrecht University, Copernicus Institute of Sustainable Development, Heidelberglaan, 2, PO Box 80115, 3508TC, Utrecht, The Netherlands \\ e University of Tennessee, Institute for a Secure and Sustainable Environment (ISSE), Knoxville, TN, USA \\ ${ }^{\mathrm{f}} \mathrm{KU}$ Leuven - University of Leuven, Centre for Economics and Corporate Sustainability, Warmoesberg 26, B-1000 Brussels, Belgium
}

\section{A R T I C L E I N F O}

\section{Article history:}

Received 26 May 2015

Accepted 26 May 2015

Available online 10 June 2015

\section{Keywords:}

Higher education for sustainable

development

Implementation of sustainable

development

Curricula design and development

Campus operations

Sustainability assessment and reporting

Organisational change management

\begin{abstract}
A B S T R A C T
During the last decades several international initiatives have emphasised that education is an imperative for societies to become more sustainable. This special volume stream is comprised of 33 papers that illustrate some of the efforts being taken by higher education institutions to contribute to sustainability. The majority of the papers were presented at the European Roundtable on Sustainable Consumption and Production - Environmental Management for Sustainable Universities conference in Istanbul, Turkey in 2013. The papers address topics such as implementation of sustainable development, stakeholder engagement and participation, campus operations, sustainability reporting and assessment, organisational change management, and curriculum development. the papers in this special volume stream provide significant steps for the higher education for sustainable development discipline by exploring new and rethink theories, approaches, concepts, methods, and frameworks, as well as providing case studies and guidelines for practitioners. As the collection of papers shows, there have been many efforts in the implementation of sustainable development in higher education institutions; however, there are still many challenges to integrate sustainable development into their systems, and many opportunities for research in the topic.
\end{abstract}

๑) 2015 Elsevier Ltd. All rights reserved.

\section{Introduction}

Higher Educational Institutions (HEIs) play an important role in transforming societies (Barth and Rieckmann, 2012). In this context, many HEIs have been incorporating environmental education and education for sustainable development (ESD) into their system (including education, research, campus operations, community outreach, assessment and reporting), making SD an integral

\footnotetext{
* Corresponding author.

E-mail addresses: tabr@fct.unl.pt (T.B. Ramos), scaeiro@uab.pt (S. Caeiro),bvan@ uniandes.edu.co (B. van Hoof),r.lozano@uu.nl (R. Lozano), donaldhuisingh@ comcast.net (D. Huisingh), kim.ceulemans@kuleuven.be (K. Ceulemans).
}

part of the institutional framework, collaborating with other higher educational institutions, encouraging on-campus sustainability life experiences, and 'Educating-the-Educators' programmes (see Cortese, 2003; Lozano, 2006; Lozano et al., 2013a,b).

There have been many efforts in the implementation of SD into HEIs' systems, e.g. from the involvement in regional development (Dlouhá et al., 2013), to the reduction of greenhouse gas emissions (Klein-Banai and Theis, 2011), and to academic leadership commitment via the inclusion of SD in their mission and vision statements (Lee et al., 2013).

Unfortunately, many of those efforts addressed only one or two of the system's elements which continues to foster compartmentalisation, due to the fact that HEIs tend to be highly complex silos (Denman, 2009). This contrasts with the recognition that 


\section{List of acronyms}

EMSU Environmental Management for Sustainable Universities

ERSCP European Roundtable on Sustainable Consumption and Production

ESD Education for Sustainable Development

HEI Higher Education Institutions

HES Higher Education System

HESD Higher Education for Sustainable Development

JCLP Journal of Cleaner Production

SD Sustainable Development

SV Special Volume

implementation of SD, if it can provide any real help to societies, must be based on holistic and system's thinking and action (see Ferrer-Balas et al., 2009; Koester et al., 2006).

Encouragingly many HEIs have integrated SD into their educational activities by designing courses with learning objectives that are clearly focussed upon holistic approaches to sustainable societal development. This requires the development and testing of new types of student assessment methods and changing many of our teaching paradigms to help to overcome the mono-disciplinary barriers to change.
This also requires developing and using communication skills and community engagement and empowerment skills in sustainable societal transformation at local and regional levels (Karatzoglou, 2013).

Although there have been some developments in the Higher Education for Sustainable Development (HESD) field, there are still numerous challenges that need to be overcome (Leal Filho et al., 2015). To achieve progress in helping societies becoming more sustainability orientated, HEIs' leaders, faculty, and students worldwide are challenged to co-work to build upon the foundations already laid to develop sustainable societies (Lozano et al., 2013b). It is also necessary to take a learning and processoriented approach, instead of focusing solely on the output of SD integration activities (Barth and Michelsen, 2013).

This Special Volume (SV) of the JCLP builds upon the published papers of the Environmental Management for Sustainable Universities (EMSU) SV published in the JCLP in 2013 (number 48), as well as upon the SVs 49 and 52 published in the JCLP in 2013. The majority of the papers in this SV were presented at the ERSCP-EMSU conference in Istanbul, Turkey in 2013.

The papers were divided into the following sections (based on their focus, as presented in Fig. 1):

- Papers 1 to 4 focus on the implementation of SD into the HEIs' system;

- Papers 5 to 9 address stakeholders, their perceptions, and their engagement in the incorporation of SD;

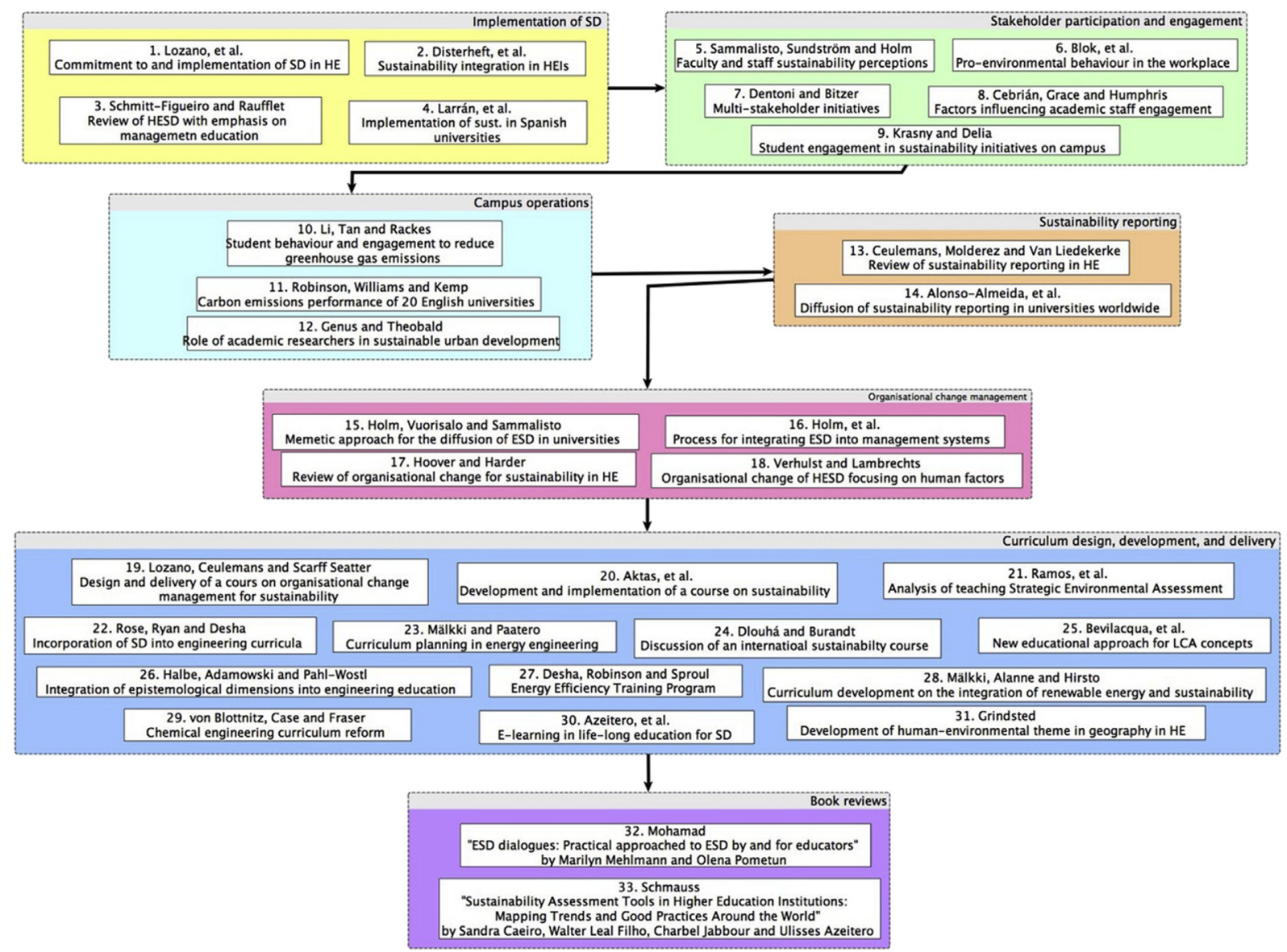

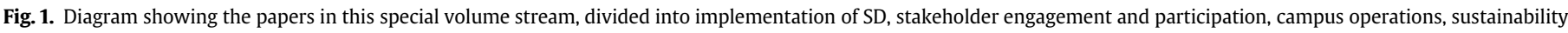
reporting and assessment, organisational change management, curriculum development, and book reviews. 
- Papers 10 to 12 present the results and findings of research on campus operations;

- Papers 13 to 14 discuss how sustainability is being assessed and reported in HEIs;

- Paper 15 to 19 focus on the dynamics of organisational change management for sustainability and how the topic is being taught in the classroom;

- Paper 20 to 31 present examples on sustainability educational approaches, and course design, development, and delivery;

- Finally, papers 32 and 33 present two reviews of HESD related books.

\section{Summary of the papers in this stream of the SV}

Paper 1. The authors investigated the commitment to and implementation of sustainable development in higher education, through a literature review and a worldwide survey. The survey responses were analysed via descriptive analysis, grounded theory, and inferential statistics. The findings showed that there have been many examples of the implementation of SD throughout the HEI system; however, they also found that most SD research has not been holistically integrated throughout the higher educational system. The authors found that there are strong links between SD commitment and its implementation The authors provided several recommendations for higher educational leaders, such as the establishment of short-, medium-, and long-term plans for the institutionalisation of SD, and the need for SD implementation throughout the entire system (Lozano et al., in this SV-a).

Paper 2. The authors explored participatory approaches contributing to sustainability integration in higher education institutions. The authors used a combination of a Delphi-method, semi-structured interviews, and focus groups with participants from twenty countries, in order to identify critical success factors of participatory approaches in sustainability assessment. The authors found that there has been an evolution away from environmental issues towards a broader sustainability approach, geared at empowerment and capacity building. The authors highlighted that the integration of participatory approaches in sustainability assessment practices can help to foster a culture of participation in universities (Disterheft et al., 2015).

Paper 3. The authors developed a systematic review of the literature on sustainability in higher education with an emphasis on management education. They analysed sixty-three articles from three sustainability-related journals, and nine managementrelated journals for the period 2003-2013. The authors highlighted three barriers in introducing sustainability in management education: (1) lack of direct support from deans and programme directors; (2) insufficient sustainability terminology for business, as managers need pragmatic concepts that integrate economic, social and environmental dimensions, and (3) lack of management educator's capabilities to transmit sustainability issues to managers The authors found that integrating sustainability into management education requires the use of student-centred pedagogical approaches, such as case studies, learning by doing, service learning, problem-based learning, and games. Horizontal and vertical integration and combined strategies were found to be needed in the curriculum orientation. A lack of consistency was noted in the concepts used, because most articles were descriptive, and focused on specific experiences in given contexts. The authors concluded that sustainability has not yet evolved into a research field in management education with broader philosophies and learning theories (Schmitt-Figueiro and Raufflet, 2015).
Paper 4. The authors analysed the extent to which Spanish universities have implemented sustainability practices into their institutions. They analysed the main factors that could explain the implementation of sustainability practices in Spanish universities. The data were collected using a survey distributed to rectors and senior management at Spanish higher educational institutions. The findings documented that the progress of implementing sustainability in many Spanish universities has been slow. The authors highlighted a number of obstacles that need to be overcome, such as the resistance to change, the lack of support from university administrators, the lack of specialization in sustainability by faculty members, and the lack of financial resources. The authors highlighted the need for Spanish universities to increase their commitment to sustainability and showed that there is still a long way to go to achieve the implementation of sustainability practices throughout all courses and curricula (Larrán Jorge et al., 2015).

Paper 5. The authors examined how faculty and staff perceive sustainability in their functions at the university. The research was based on a long-term sustainability implementation and training case study, within a 14001 certified environmental management system. The study was supported by open-ended survey questions, using a Swedish university case. The authors proposed a model for the development of sustainability competences and its institutionalization. The main findings showed a large variation in the perceptions on the contribution to sustainability. The authors emphasized that top management's inspiration on different university levels is essential for sustainability integration. Continuous training and routines contribute to movement towards institutionalisation of sustainability activities and to following up the process in universities (Sammalisto et al., 2015).

Paper 6. The authors developed a model that predicted the internal and external factors that could predict pro-environmental behaviour in the workplace. The proposed model was tested among employees of a university in the Netherlands. The authors concluded that the theory of planned behaviour could explain pro-environmental behaviour in the workplace and that clear differences exist between the factors influencing proenvironmental behaviour in households and in the workplace. Moreover, other factors such as leadership support and exemplary pro-environmental behaviour by leaders helped to catalyse pro-environmental behaviour in the workplace, and had significantly positive impacts on employee's intentions to act proenvironmentally (Blok et al., 2015).

Paper 7. The authors analysed the role of universities in multistakeholder initiatives related to complex global sustainability problems. Their analytical framework was based on three theoretical pillars, i.e. wicked problem theory, multi-stakeholder initiatives, and theories on the university roles in sustainable development. A database included 41 global agriculture and food sector initiatives and 51 interviews with participants, which provided the empirical information to gain insights into how academics can collaborate in addressing wicked problems. The findings showed that academics played roles as knowledge experts, agenda-setting advisors and facilitators in multi-stakeholder initiatives. The study also revealed that academics engaging in multistakeholder initiatives have much potential for making significant contributions toward advancing a university's organisational goals, such as performing high quality research addressed to 'solve' sustainability-related problems (Dentoni and Bitzer, 2015).

Paper 8 . The authors explored the factors influencing the academic staff's engagement, as well as their views and visions in relation to ESD at the University of Southampton. This research was implemented as an exploratory action research study based on interviews with academic staff members from different disciplines and was used in a facilitator role for curriculum development by 
one of the authors. The study results suggested that although academics might have a personal interest and motivation to engage in ESD, many different factors blocked their engagement. This study provided evidence on different views and visions of academics in relation to ESD and identified a number of contradictions between its principles and the roles of higher education (Cebrián et al., 2015).

Paper 9. In this paper the authors explored the need for more substantive and formal integration of student engagement in stewardship of open spaces and natural areas on within the university's sustainability initiatives. Their study was based on a literature review and on interviews with members of a student organisation focused on voluntary stewardship of campus open spaces and natural areas. The authors underscored the need for a greater emphasis on student involvement in nature-based activities in university sustainability efforts and highlighted not only direct benefits to the campus environment, but also on enhancement of the students' sense of place and mental well-being. The study showed that nature-based stewardship complements other aspects of sustainability education, such as those focused on reducing consumption and energy use, and supports a holistic approach to university sustainability initiatives (Krasny and Delia, 2015).

Paper 10. The authors analysed carbon footprints of student behaviour and identified carbon mitigation opportunities by raising student consciousness of greenhouse gas emissions and by implementation of campus-wide practices to decrease these air pollutants. A carbon footprint model was developed, based on survey responses of over 1000 students of a university in Shanghai and upon their utility data and emissions. The model considered students' activities such as daily life, academic activities and transport. The results showed that the "daily life" category accounted for the largest part (65\%) of the carbon footprint, which was due to three activities: dining, showering and dorm plug loads. Moreover, the study found that Chinese students had a relatively lower carbon footprint than their counterparts in the US and Europe, mainly due to less transportation. Female students, undergraduates, and rural students had lower footprints than men, graduate students and students from the city and its suburbs because they eat more frequently in common dining rooms, used the central library for studying and travelled less during the weekends. The study provided empirical evidence of the benefits of system-level organisational planning for human behaviour in universities (Li et al., 2015).

Paper 11. The authors compared the carbon performance of twenty institutions in the English "Russell Group" of researchintensive universities to their self-set targets. Three key performance indicators were used: full-time equivalent staff/student numbers, gross internal area and institutional income. The University of Southampton was used as the case study based upon a staff and student questionnaire, which highlighted the range of electricity consumption activities, increasing electricity demand, and subsequent emissions. The authors sought to document that appropriate target setting and legitimate emission reduction strategies are essential for meaningful changes locally and on a global scale. They also emphasised the use of appropriate key performance indicators to foster action towards carbon reductions (Robinson et al., 2015).

Paper 12. The authors discussed the role of academic researchers in contributing to sustainable urban development. The study examined the 'Newcastle Low Carbon Neighbourhoods' project, designed to implement household energy efficiency measures in an economically disadvantaged district. The authors used action research as their research approach. They reviewed workshop participation notes and stakeholder meeting minutes from 2007 to
2011 as empirical data. Self-reflection was used to identify the role of the academics in the project, and to study the factors influencing their participation. The findings showed that academic researchers played multiple, and sometimes, conflicting roles in the project as intellectual overseers, researchers, and consultants. National research funding agency representatives questioned the validity of certain project outcomes, given household density and reciprocal ties that may have influenced the collaboration among the researchers and other contributors. The authors concluded that more conventional project arrangements might have overcome the difficulties of ensuring independent assessments (Genus and Theobald, 2015).

Paper 13. The authors presented a comprehensive review of the literature on sustainability reporting in higher education, in order identify gaps and inconsistencies in the literature, to provide guidance on new paths for research. The research findings showed that the topic was mainly addressed in a fragmented way in the literature, and that more in-depth studies are needed. The study also highlighted that organisational change, stakeholder engagement processes, and reporting indicators and their links with sustainability reporting are areas needing further research (Ceulemans et al., 2015).

Paper 14. These researchers investigated the current situation and envisioned future perspectives of worldwide diffusion of sustainability reporting in universities. A combination of qualitative and quantitative methods was used, based on the data from the Global Reporting Initiative Disclosure Database, and from sustainability reports present in this database. The results revealed that the diffusion of sustainability reporting is still at an early stage in universities, and no major increase in diffusion is expected based on the current trends. The authors emphasized that actions such as pressure from relevant stakeholders, e.g. students or faculty, should be encouraged and built upon to persuade university leaders to adopt reporting standards and to highlight the benefits of sustainability reporting (Alonso-Almeida et al., 2015).

Paper 15. The authors proposed a memetic approach to study how management systems enhance the diffusion of ESD in universities. The research setting was defined by a case study of eleven Nordic universities, engaged in ESD and management systems in Denmark, Finland, Iceland, Norway and Sweden. The data were collected from reports and seminar presentations. The results showed how management systems and ESD in universities can be considered as successful memes, as their diffusion in the universities studied showed similar patterns. In addition, both concepts showed variation in their content, frequency of acceptance and persistence of content from the source recipient. Moreover, management systems enhanced the potential for ESD. The study offered a new approach for looking at the diffusion of ESD in universities and presented mechanisms to strengthen its development (Holm et al., 2015-b).

Paper 16. The authors developed a process framework for integrating ESD into management systems based on identified drivers and barriers, piloted at Nordic universities (this paper is linked with the research presented in paper 15). The framework included planning, assessment, monitoring and can be applied for visualizing the implementation of ESD. The authors concluded that quality assurance is a significant driver, and that the participatory process within this study demonstrated that the framework could be used for enhancing implementation of ESD in universities (Holm et al., 2015-a).

Paper 17. The authors presented a review on the complexities of organisational change for sustainability in higher education. The authors used a meta-ethnography of thirteen qualitative studies from peer-reviewed academic publications. Using a grounded theory approach, nine themes were identified and synthesized in 
order to develop an in-depth understanding of organisational change processes for sustainability. The authors identified the need to recognize existing tensions and contradictions through reflexive practice and genuine dialogue, as well as to develop flexible structures and moving towards "double loop" learning within institutions. According to the authors, the meta-ethnography also presented a look beyond the surface of what has become an increasingly important area of institutional change in higher education, and has the potential to inform practice, and to contribute to emerging research imperatives (Hoover and Harder, 2015).

Paper 18. The research in this paper provided an understanding of the process of organisational change towards sustainable development in higher education by studying the human factors involved in this process. The literature review provided an overview of success factors and obstacles for change with a special emphasis on factors related to "people", such as resistance, communication, empowerment and organisational culture. Leuven University College was selected as the basis for the case study, due to its involvement in ESD for more than ten years. A conceptual model was developed to obtain an in-depth understanding of human related barriers to the integration of sustainability in higher education. The lessons learned highlighted how differences in human factors could support or hamper the integration process in subsequent stages. The analyses revealed how diverse barriers to change are linked to each other, and influence each other. The authors stated that the integration process cannot be seen as a continuously proceeding process, and that there is a risk of a rebound effect, sustainabilityfatigue and the demotivation of individuals (Verhulst and Lambrechts, 2015).

Paper 19. The authors presented the process of designing and delivering a new course on organisational change management for sustainability for the BA Environment and Business degree at the University of Leeds, UK. The course was developed based on holism and a constructivist position to help deal with the complexities of sustainability and organisational change management. During the process a number of challenges had to be overcome, such as adhering to guidelines in course design, linking the course to other courses in the curriculum, designing the assessment, and teaching a new topic with limited academic literature. The course was evaluated through student feedback. Based upon the student's responses, the authors emphasised the need for a more complete, systematic, robust, and focused approach to implementation of ESD, specifically on course design and delivery, by using theories of teaching and learning and linking the course objectives, delivery, and assessment to holistic integration of ESD in all courses and curricula (Lozano et al., 2015-b).

Paper 20. The authors of this paper performed a case study of the development and implementation of a university-wide freshman course, centered on the topic of sustainability. The research assessed the experiences of a group of faculty in developing and implementing the course in the University of New Haven, USA. The research included an analysis of the course development and structure, including the description of the goals and learning outcomes. The course was developed and presented by faculty members from widely differing disciplines working together to teach the course. This resulted in a diversity of perspectives, but also introduced divergent expectations among faculty and a lack of coherence in achieving the goals of the course. The researchers observed that the lack of prior knowledge of students limited their engagement in discussions. The authors recommended that institutions that attempt to organise a similar course should allocate sufficient time to develop the course, ideally a year in advance. They also found that leadership among faculty and/or the establishment of a governance structure is essential to motivate faculty members to become involved in the course (Aktas et al., 2015).

Paper 21. The authors investigated the processes of teaching Strategic Environmental Assessment approaches in higher education. The authors analysed two cases, one from Portugal (with 260 educational programmes) and the other from Brazil (with 452 educational programmes). The authors analysed the curricula of bachelor's and master's programmes of the two regions, using content analysis. The results showed a medium state of integration of strategic environmental assessment in the curricula. The authors underscored that there is a need to design courses specialised in Strategic Environmental Assessment. The authors concluded that, in general, there are a limited number of courses on strategic environmental assessment, and that, given its importance in national and international legislation, there should be more emphasis on this issue and a better incorporation of those topics into HEIs' curricula (Ramos et al., 2015).

Paper 22. The authors of this article examined the incorporation of ESD into engineering curricula and its impact on student learning. The study was done in a first year engineering degree at Monash University, Australia. The authors analyzed how the curriculum was designed and developed. This process included identifying the skills needed by the students and how the faculty members were guided to fulfil those needs. A web-portal was used to facilitate the implementation. Some of the key topics included in the curriculum were life cycle analysis, systems thinking, and critical thinking. The study used a priori and a posteriori surveys designed to explore the students' self-reported sustainability knowledge before and after taking the course. The authors concluded that a holistic approach to curriculum renewal could help to embed sustainability in the minds of students (Rose et al., 2015).

Paper 23. The authors explored the practical and theoretical principles of curriculum-centred strategic planning in energy engineering education, and analysed how curriculum planning and its implementation are essential in the teaching structures and student experiences. The authors analysed a Finnish case, i.e. Aalto University, using a student survey and teacher interviews, based upon content analysis tools. Overall, the authors identified the main strengths and good practices in curriculum planning. They found that those practices could have wider impacts in the engineering education context. The research findings underscored that the curriculum is a key factor in defining programme outcomes (Mälkki and Paatero, 2015).

Paper 24. The authors explored an international sustainabilityoriented teaching and learning programme in higher education, where theoretical concepts were applied in teaching practice. The Interdisciplinary Study Programme on Sustainability (ISPoS), run by Leuphana University of Lüneburg and the Charles University Environment Centre in Prague, were investigated. The authors examined the programme goals, the role of the learning environment, the didactic and teaching approach, the modular structure and the student assessment processes. The research framework was supported by a mixed methods approach that used qualitative and quantitative methods, and provided an analysis of student perceptions of the learning process and of the learning environment. The student's perceptions of the learning process showed that their attitudes and approaches to learning ranged from a surface approach to a deep approach. This research contributed to understanding the roles of the learning environment in achieving educational goals for sustainability (Dlouhá and Burandt, 2015).

Paper 25. The authors developed a new educational approach for learning Life Cycle Assessment concepts by applying them to the daily practice of the preparation of meals. The authors developed a 
learning game, called “Cook \& Teach", in an engineering course at Università Politecnica delle Marche (Ancona, Italy). The game was designed to help to change the students' knowledge, attitudes, motivation and engagement for SD. The authors highlighted that this type of educational approach is a valuable and interesting way to teach Life Cycle Assessment principles, and that it stimulated the students' attention and participation (Bevilacqua et al., 2015).

Paper 26. The authors investigated some of the epistemological dimensions of sustainability issues and explored how they can be integrated into engineering education. Based on a literature review, they identified five different paradigms of engineering for sustainable development, including: "predict and control", "the economic paradigm", "stakeholder involvement", "adaptive management", and "traditional paradigm". A case study on sustainable flood management was used to assess the relevance of a system's science approach to paradigms and of their relevance for engineering practice. An iterative learning approach, including lectures, exercises and project work, was proposed, based on the experiences of the authors in teaching SD paradigms in engineering courses in McGill University, Canada and at the University of Osnabruck, Germany. The contributions of this research provided conceptual approaches for curriculum development of academic courses in engineering for SD (Halbe et al., 2015).

Paper 27. The authors of this research amplified upon the lessons learned from an initiative within the Energy Efficiency Training Program, led by the state government of New South Wales (NSW), Australia. Two leading NSW universities were awarded and funded to develop energy efficiency courses for engineers at undergraduate, and at postgraduate levels, as well as for use in continuing professional development. The authors presented and analyzed the contextual framework of the program, followed by a synthesis of key learnings, and implications of the project's efforts to embed energy efficiency within higher educational engineering curricula based on the insights gained through three external evaluations between 2011 and 2013. The project demonstrated the power of collaborative leadership among government, industry and higher education in driving the energy efficiency agenda. The objective of the paper was to share these lessons and to assist other organisations in Australia and throughout the world about benefits and tools for planning and implementing similar initiatives (Desha et al., 2015).

Paper 28. This research team examined a new curriculum development method to quantify the integration of renewable energy and sustainability in energy degree programmes, using a Finnish case study, i.e. Aalto University's energy degree programme. Quantitative and qualitative data from the learning outcomes of the energy programmes were collected and analysed. The results revealed that renewable energy and sustainability were unevenly embedded in the various majors of the energy programme, which were analysed for this study. The authors stressed the need for collaboration in curriculum development among the teachers responsible for planning the energy courses (Mälkki et al., 2015).

Paper 29. The authors examined a curriculum reform process in chemical engineering at the University of Cape Town to introduce sustainable development topics. The study described a curriculum in which the new first year course integrated a "natural foundations" strand. The course confronted the students with complex situations from the outset. The authors stressed the feasibility and benefits of reforming core undergraduate engineering curricula to incorporate a focus on SD from the first year of study onwards (von Blottnitz et al., 2015).

Paper 30. The authors of this research investigated the relevance and effectiveness of e-learning in life-long ESD, based on the experiences from Universidade Aberta in Portugal. The authors analysed the expectations and experiences from bachelor's, master's and doctoral programmes within six dimensions: general expectations; learning quality; teaching resources; pedagogical tools and evaluation; acquired competences in ESD; satisfaction and interactions; and reasons to pursue enrolment in a new programme. The results showed that the students were highly motivated to enrol in the courses, which empowered them to improve their sustainability knowledge. The authors were convinced that e-learning programmes are good alternatives for traditional in-class teaching, especially for students who hold full time jobs. The study showed that sustainability can be, and currently is, being incorporated in many stages of education (Azeitero et al., 2015).

Paper 31. The author provided a retrospective view of the development of the human-environmental theme in higher education in geography. The author analysed contested ideas of sustainability approaches and their significance given by faculty. The framework related spatio-temporal tides and waves of the humanenvironment with different sustainability typologies in education, such as fact-based sustainability learning, norm-based sustainability learning and policy-based sustainability learning. The empirical analyses were based on interviews with thirty-one geographers from three Danish universities. The outcomes identified contradictions, and frictions and fractions, as researchers found sustainability themes to be essential for educating geographers, but they were reluctant to use the concept of sustainability in the classroom. This produced a number of dilemmas, because geographers both seek to distance themselves from politics while at the same time elucidating them. The implications of this research highlighted that scientists, scholars and practitioners must deconstruct concepts such as drivers and barriers to change, and transform challenges into opportunities, on which ESD must be built. Similarly, the researcher found that scholars across disciplines should reflect more carefully on the contradictions and paradoxes of traditional ESD approaches. The author underscored that students should be challenged to think critically about the subtle political ecologies engaged in such approaches (Grindsted, 2015).

Paper 32. The author reviewed the book "ESD Dialogues: Practical approaches to Education for Sustainable Development by and for Educators", by Marilyn Mehlmann and Olena Pometun (2013). According to Mohamad, this book was mainly written for educators and researchers interested in teaching and learning of ESD, for both formal and informal education. "ESD Dialogues" is an exploratory and dialectical reading, designed to stimulate reflection rather than instruction, and educating about the pedagogical methods, approaches, tools, and skills required to bring about the transformative essence of sustainable development (Mohamad, 2015).

Paper 33. The author reviewed the book "Sustainability Assessment Tools in Higher Education Institutions: Mapping Trends and Good Practices Around the Word" edited by Caeiro et al. This collection of papers addressed themes involving international efforts related to the use of the assessment tools for HESD. The book offers a valuable collection of works with a broad geographic and interest boundaries for those who are new to the subject or for those seeking a deeper understanding of the available tools and trends (Schmauss, 2015).

\section{Conclusions}

During recent decades, there has been an increase in the interest of HEIs in sustainability, and in its implementation in diverse elements of HEI systems. There have been many examples of implementation, as this EMSU stream's papers documented with findings that ranged from analyses of the implementation ESD into courses and curricula, to stakeholder engagement and 
participation, to improvements of campus operations, sustainability assessment and reporting, as well as underscoring its impacts upon organisational change management, and curricula development. Many of the efforts addressed one of the system's elements; while there is increasing evidence that HEIs are moving towards more holistic and systemic approaches when addressing and dealing SD, as many of the papers in this stream highlighted.

There have been major developments in the HESD field; nonetheless, there are still many challenges, such as better integration ESD into curricula, research, and most importantly holistically into their systems, faced by HEIs' stakeholders in practice and in theory, but at the same time HEIs have a high potential to make rapid progress in implementing SD into their operations, curricula, and research. The papers in this SV provide a strong basis to further develop theories and to dramatically improve practice in HESD in HEIs.

\section{References}

Aktas, C.B., Whelan, R., Stoffer, H., Todd, E., Kern, C.L., 2015. Developing a universitywide course on sustainability: a critical evaluation of planning and implementation. J. Clean. Prod. 106, 216-221. http://dx.doi.org/10.1016/j.jclepro.2014 11.037.

Alonso-Almeida, M.M., Marimon, F., Casani, F., Rodriguez-Pomeda, J., 2015. Diffusion of sustainability reporting in universities: current situation and future perspectives. J. Clean. Prod. 106, 144-154. http://dx.doi.org/10.1016/j.jclepro.2014 02.008 .

Azeitero, U.M., Bacelar-Nicolau, P., Caetano, F.J.P., Caeiro, S., 2015. Education for sustainable development through e-learning in higher education: experiences from Portugal. J. Clean. Prod. 106, 308-319. http://dx.doi.org/10.1016/j.jclepro. 2014.11.056.

Barth, M., Michelsen, G., 2013. Learning for change: an educational contribution to sustainability science. Sustain. Sci. 8 (1), 103-119. http://dx.doi.org/10.1007/ s11625-012-0181-5.

Barth, M., Rieckmann, M., 2012. Academic staff development as a catalyst for curriculum change towards education for sustainable development: an output perspective. J. Clean. Prod. 26, 28-36. http://dx.doi.org/10.1016/ j.jclepro.2011.12.011.

Bevilacqua, M., Ciarapica, F.E., Mazzuto, G., Paciarotti, C., 2015. “Cook \& Teach”: learning by playing. J. Clean. Prod. 106, 259-271. http://dx.doi.org/10.1016/j. jclepro.2014.11.085.

Blok, V., Wesselink, R., Studynk, O., Kemp, R., 2015. Encouraging sustainability in the workplace: a survey on the pro-environmental behaviour of university employees. J. Clean. Prod. 106, 55-67. http://dx.doi.org/10.1016/j.jclepro.2014.07. 063.

Cebrián, G., Grace, M., Humphris, D., 2015. Academic staff engagement in education for sustainable development. J. Clean. Prod. 106, 79-86. http://dx.doi.org/10. 1016/j.jclepro.2014.12.010.

Ceulemans, K., Molderez, I., Van Liedekerke, L., 2015. Sustainability reporting in higher education: a comprehensive review of the recent literature and paths for further research. J. Clean. Prod. 106, 127-143. http://dx.doi.org/10.1016/j.jclepro. 2014.09.052.

Cortese, A.D., 2003. The critical role of higher education in creating a sustainable future. Plan. High. Educ. 31 (3), 15-22.

Denman, B.D., 2009. What is a university in the 21st century? High. Educ. Manag. Policy. http://dx.doi.org/10.1787/hemp-v17-art8-en.

Dentoni, D., Bitzer, V., 2015. The role(s) of universities in dealing with global wicked problems through multi-stakeholder initiatives. J. Clean. Prod. 106, 68-78. http://dx.doi.org/10.1016/j.jclepro.2014.09.050.

Desha, C., Robinson, D., Sproul, A., 2015. Working in partnership to develop engineering capability in energy efficiency. J. Clean. Prod. 106, 283-291. http://dx. doi.org/10.1016/j.jclepro.2014.03.099.

Disterheft, A., Caeiro, S., Azeitero, U.M., Leal Filho, W., 2015. Sustainable universities - a study of critical success factors for participatory approaches. J. Clean. Prod. 106, 11-21. http://dx.doi.org/10.1016/j.jclepro.2014.01.030.

Dlouhá, J., Burandt, S., 2015. Design and evaluation of learning processes in an international sustainability oriented study programme. In search of a new educational quality and assessment method. J. Clean. Prod. 106, 247-258. http://dx.doi.org/10.1016/j.jclepro.2014.09.096.

Dlouhá, J., Huisingh, D., Barton, A., 2013. Learning networks in higher education: universities in search of making effective regional impacts. J. Clean. Prod. 49, 5-10. http://dx.doi.org/10.1016/j.jclepro.2013.01.034.

Ferrer-Balas, D., Buckland, H., de Mingo, M., 2009. Explorations on the University's role in society for sustainable development through a systems transition approach. Case-study of the Technical University of Catalonia (UPC). J. Clean. Prod. 17 (12), 1075-1085. http://dx.doi.org/10.1016/ j.jclepro.2008.11.006

Genus, A., Theobald, K., 2015. Roles for university researchers in urban sustainability initiatives: the UK Newcastle Low Carbon Neighbourhoods project. J. Clean. Prod. 106, 119-126. http://dx.doi.org/10.1016/j.jclepro.2014. 08.063.

Grindsted, T.S., 2015. Educating geographers in an era of the anthropocene: paradoxical natures - paradoxical cultures. J. Clean. Prod. 106, 320-329. http://dx. doi.org/10.1016/j.jclepro.2014.10.086.

Halbe, J., Adamowski, J., Pahl-Wostl, C., 2015. The role of paradigms in engineering practice and education for sustainable development. J. Clean. Prod. 106, 272-282. http://dx.doi.org/10.1016/j.jclepro.2015.01.093.

Holm, T., Sammalisto, K., Grindsted, T.S., Vuorisalo, T., 2015a. Process framework for identifying sustainability aspects in university curricula and integrating education for sustainable development. J. Clean. Prod. 106, 164-174. http://dx.doi. org/10.1016/j.jclepro.2015.04.059.

Holm, T., Vuorisalo, T., Sammalisto, K., 2015b. Integrated management systems for enhancing education for sustainable development in universities: a memetic approach. J. Clean. Prod. 106, 155-163. http://dx.doi.org/10.1016/j.jclepro.2014. 03.048 .

Hoover, E., Harder, M.K., 2015. What lies beneath the surface? the hidden complexities of organizational change for sustainability in higher education. J. Clean. Prod. 106, 175-188. http://dx.doi.org/10.1016/j.jclepro.2014.01.081.

Karatzoglou, B., 2013. An in-depth literature review of the evolving roles and contributions of universities to education for sustainable development. J. Clean. Prod. 49, 44-53. http://dx.doi.org/10.1016/j.jclepro.2012.07.043.

Klein-Banai, C., Theis, T.L., 2011. An urban university's ecological footprint and the effect of climate change. Ecol. Indic. 11 (3), 857-860. http://dx.doi.org/10.1016/ j.ecolind.2010.11.002.

Koester, R.J., Eflin, J., Vann, J., 2006. Greening of the campus: a whole-systems approach. J. Clean. Prod. 14 (9-11), 769-779. http://dx.doi.org/10.1016/ j.jclepro.2005.11.055

Krasny, M.E., Delia, J., 2015. Natural area stewardship as part of campus sustainability. J. Clean. Prod. 106, 87-96. http://dx.doi.org/10.1016/j.jclepro.2014.04. 019.

Larrán Jorge, M.L., Herrera Madueño, J., Calzado Cejas, M.Y., Andrades Peña, F.J., 2015. An approach to the implementation of sustainability practices in Spanish universities. J. Clean. Prod. 106, 34-44. http://dx.doi.org/10.1016/j.jclepro.2014. 07.035.

Leal Filho, W., Manolas, E., Pace, P., 2015. The future we want: key issues on sustainable development in higher education after Rio and the UN decade of education for sustainable development. Int. J. Sustain. High. Educ. 16 (1), 112-129.

Lee, K.-H., Barker, M., Mouasher, A., 2013. Is it even espoused? an exploratory study of commitment to sustainability as evidenced in vision, mission, and graduate attribute statements in Australian universities. J. Clean. Prod. 48, 20-28. http:// dx.doi.org/10.1016/j.jclepro.2013.01.007.

Li, X., Tan, H., Rackes, A., 2015. Carbon footprint analysis of student behaviour for a sustainable university campus in China. J. Clean. Prod. 106, 97-108. http://dx. doi.org/10.1016/j.jclepro.2014.11.084.

Lozano, R., 2006. Incorporation and institutionalization of SD into universities. Breaking through barriers to change. J. Clean. Prod. 14, 787-796. http:// dx.doi.org/10.1016/j.jclepro.2005.12.010.

Lozano, R., Ceulemans, K., Alonso-Almeida, M., Huisingh, D., Lozano, F.J., Waas, T., Lambrechts, W., Lukman, R., Hugé, J., 2015a. A review of commitment and implementation of sustainable development in higher education: results from a worldwide survey. J. Clean. Prod. (in this special volume) http://dx.doi.org/10. 1016/j.jclepro.2014.09.048

Lozano, R., Ceulemans, K., Scarff Seatter, C., 2015b. Teaching organisational change management for sustainability: designing and delivering a course at the University of Leeds to better prepare future sustainability change agents. J. Clean. Prod. 106, 205-215. http://dx.doi.org/10.1016/j.jclepro.2014.03.031.

Lozano, R., Lozano, F.., Mulder, K., Huisingh, D., Waas, T., 2013a. Advancing higher education for sustainable development: international insights and critical reflections. J. Clean. Prod. 48, 3-9. http://dx.doi.org/10.1016/j.jclepro.2013.03.034.

Lozano, R., Lukman, R., Lozano, F.J., Huisingh, D., Lambrechts, W., 2013b. Declarations for sustainability in higher education: becoming better leaders, through addressing the university system. J. Clean. Prod. 48, 10-19. http://dx.doi.org/ 10.1016/j.jclepro.2011.10.006.

Mälkki, H., Alanne, K., Hirsto, L., 2015. A method to quantify the integration of renewable energy and sustainability in energy degree programmes: a Finnish case study. J. Clean. Prod. 106, 239-246. http://dx.doi.org/10.1016/j.jclepro.2014. 10.012.

Mälkki, H., Paatero, J.V., 2015. Curriculum planning in energy engineering education. J. Clean. Prod. 106, 292-299. http://dx.doi.org/10.1016/j.jclepro.2014.08. 109.

Mohamad, Z.F., 2015. Book review: ESD dialogues: practical approaches to education for sustainable development by and for educators, Marilyn Mehlmann, Olena Pometun. Books on demand, Germany (2013), 143 pages, ISBN: 978-917463-206-4. J. Clean. Prod. 106, 330-331. http://dx.doi.org/10.1016/j.jclepro. 2015.03.034.

Ramos, T., Montaño, M., Joanaz de Melo, J., Souza, M.P., Carvalho de Lemos, C., Domingues, A.R., Polido, A., 2015. Strategic environmental assessment in higher education: Portuguese and Brazilian cases. J. Clean. Prod. 106, 222-228. http:// dx.doi.org/10.1016/j.jclepro.2014.12.088.

Robinson, O., Kemp, S., Williams, I., 2015. Carbon management at universities: a reality check. J. Clean. Prod. 106, 109-118. http://dx.doi.org/10.1016/j.jclepro. 2014.06.095.

Rose, G., Ryan, K., Desha, C., 2015. Implementing a holistic process for embedding sustainability: a case study in first year engineering, Monash University, 
Australia. J. Clean. Prod. 106, 229-238. http://dx.doi.org/10.1016/j.jclepro.2015. 02.066 .

Sammalisto, K., Sundström, A., Holm, T., 2015. Implementation of sustainability in universities as perceived by faculty and staff - a model from a Swedish university. J. Clean. Prod. 106, 45-54. http://dx.doi.org/10.1016/j.jclepro.2014.10. 015.

Schmauss, S., 2015. Book review: sustainability assessment tools in higher education institutions: mapping trends and good practices around the world, Sandra Caeiro, Walter Leal Filho, Charbel Jabbour, Ulisses M. Azeitero (Eds.). Springen, New York (2013), 432pp., ISBN: 9783319023755. J. Clean. Prod. 106, 332. http:// dx.doi.org/10.1016/j.jclepro.2014.12.049.
Schmitt-Figueiro, P., Raufflet, E., 2015. Sustainability in higher education: a systematic review with focus on management education. J. Clean. Prod. 106, 22-33. http://dx.doi.org/10.1016/j.jclepro.2015.04.118.

Verhulst, E., Lambrechts, W., 2015. Fostering the incorporation of sustainable development in higher education. Lessons learned from a change management perspective. J. Clean. Prod. 106, 189-204. http://dx.doi.org/10.1016/j.jclepro. 2014.09.049.

von Blottnitz, H., Case, J.M., Fraser, D.M., 2015. Sustainable development at the core of undergraduate engineering curriculum reform: a new introductory course in chemical engineering. J. Clean. Prod. 106, 300-307. http://dx.doi.org/10.1016/j. jclepro.2015.01.063. 